\title{
Homeownership Motivation, Rationality And Housing Prices: Evidence From Gloom, Boom And Bust-And-Boom Economies
}

\begin{abstract}
By focusing on three types of homebuyers we address three questions: i) do households drive housing prices? ii) do households and landlords act rationally in their buying decision? iii) is the market conducive to promoting homeownership or is it a speculators' territory? We use system GMM estimations in 1970-2016, for 34 economies clustered as gloom, boom or bustand-boom and we provide novel evidence that all three types of homebuyers contribute significantly in determining housing prices. Households and landlords seem to act irrationally as their decisions are less affected by housing affordability and shrinking yields.
\end{abstract}

Keywords: Housing Prices, Homebuyers, Rational Behaviour, Speculation, System GMM.

JEL Classification: C22; G12; R31. 


\section{Introduction}

The housing sector satisfies an essential need of households (Zhu, 2014). Conversely, inadequate housing constitutes a threat to society that arises from the inherent problems encountered also in advanced economies, namely, poverty, homelessness etc. In this sense, when the housing sector fails to satisfy the needs of households can become a destabilizing factor not only of social cohesion and sustainable livelihoods but also for financial stability and the real economy.

Housing varies greatly in terms of quality but can be consumed either through ownership or rent. Alternatively, houses can be viewed as an income-generating asset, as a collateral for debt, or even as a commodity, the value of which, depends on various factors. Thus, housing makes a large component of wealth, investment but also speculation.

Over time, housing prices have soared reaching unprecedented proportions. This rising of housing costs of all types and tenures across many economies has been frequently referred to as 'a housing crisis' as housing costs of all types command a disproportionate amount of peoples' income.

A close look at the IMF's Global House Price Index (2017) suggests that the significant increase in housing prices since 2000 was shortly punctuated by the Global Financial Crisis in 2007-8. Nearly ten years after the crisis housing prices have already started to recover and in certain countries exceeded their pre-crisis prices (Ahir and Loungani, 2016). An effective way, to explain the continuous rise in housing prices is to gain an insight into the underlying motivation for residential property procurement.

To understand the drivers of the housing market and hence housing prices, it is imperative to focus on three different types of homeowners or buyers, namely, the occupants or household buyers, the investors-landlords or landlords and the investor-speculators or speculators. 
Traditional studies have focused on the consumer's impact on housing prices, while recent research is considering investor motivations as well.

This paper seeks to contribute to the housing literature by focusing on the determination of house price rationality through buyers' motivation. The evidence produced is novel as it is the first study to consider the perspectives of three different types of housing buyers: owneroccupants, investor-landlords and investor-speculators.

The rest of the paper is organized as follows: section 2 reviews the extant literature whilst section 3 spells out the methodological framework used for the empirical investigation. Section 4 discusses the results obtained and section 5 elaborates on the policy implications in light of the evidence generated. Finally, section 6 concludes.

\section{Literature Review}

Undoubtedly, the macroeconomic determinants of housing demand and prices have been extensively researched in the respective literature. More specifically, Baffoe-Bonnie (1998) in a study measuring the impact of monetary policy and macroeconomic aggregates on housing prices in the United States found that housing markets are susceptible to shocks arising in the labour markets and mortgage rates, with varying degrees of impact on prices and units sold in different regions and time periods. However, these variables alone are insufficient to explain the fluctuation of values (Baffoe-Bonnie, 1998). Ramchander, et al. (2003) by exploring the effects of macroeconomic announcements on interest rates found that reports on higher inflation and economic growth positively influence interest and hence mortgage rates. In another study that accounted for frictions in credit markets Aoki et al. (2004) provide evidence on the basis of which lowering transactions cost of borrowing against equity increases the influence of policy shocks on consumption, but cushions housing prices. Beltratti and Morana (2010) study for the G7 countries found that global 
macroeconomic shocks influence housing in the same way they influence economic activity and stock returns. The authors concluded that these shocks play a significant role in the fluctuations of housing prices, where a bi-directional relationship exists, wherein shocks in housing prices affect the macro-economy more than the shocks in the stock market. Grimes and Hyland (2014) in a study on the impact of credit and migration shocks on house prices and housing supply in New Zealand found that both shocks cause substantial and prolonged cyclical adjustments in each variable.

Cesa-Bianchi, et al. (2015) by comparing housing cycles between developed and emerging economies find that prices in emerging economies grow faster, but are more volatile and less synchronized. Furthermore, a global liquidity shock affects housing prices and consumption in emerging markets much more than they do in developed economies.

On a different note, Ho And Wong (2006) found evidence that the introduction of privatization programmes in Hong Kong caused structural breaks in house prices that were more pronounced than those resulted from the Asian Financial Crisis.

Typically, house purchases are financed by a combination of personal income and mortgage loans, leveraged in some cases over four times. Arceluz and Meltzer (1973) found that the principal determinants of housing equations are relative prices, interest rates, income and real wealth whilst Reichart (1990) found regional housing prices to react uniformly to national factors like interest rates, but exhibit unique reactions to local factors such as population, employment, and income trends. In an interesting study on the connection between house prices, income and interest rates for 15 OECD countries Kishor and Marfatia (2017) found that in the short-run, changes in housing prices move independently from income and interest rates, while in the long run, permanent changes have the expected linkages towards housing prices, positive for personal income and negative for interest rates. Further evidence from a dynamic general equilibrium model for the U.S. economy was produced by Liu et al. (2016) 
suggesting that land prices and unemployment are inversely related, while shocks affecting land prices also created significant volatility in unemployment.

In recent years many attempts have also been made to relate rent to housing-price movements. In particular, Gallin (2008) by looking into the capability of the rent to price ratio in predicting real rents and prices found that this ratio has some predictive power for real prices over 4-year periods, but failed to predict changes in real rent over the same period. Additional evidence has also been provided by Goswami and Tan, (2012), Piazzesi et al. (2007), Hiebert and Sydow (2011) Liu et al. (2016) and Lai and Order (2017).

Housing demand is partly driven by individuals believing in the future appreciation of housing prices in the hope of making a profit, who are known as speculators. According to Schiller (1990), rational speculation follows lagged price appreciation as described by the positive feedback theory. Despite the fact that price speculation is considered to be a factor that drives changes in housing prices the evidence is rather sparse. In this context, Harris (1989) elaborated on the role of future appreciation in driving housing prices whilst Xiao and Park (2010) explored the role of rational speculative demand in Korea's housing prices, where they found the rational speculative bubble to be a significant driver in explaining the growth in housing values. In the same spirit, Fu and Qian (2014) provided evidence on the impact of speculators engaging in feedback or momentum trading in the housing market, particularly their effect on price overreaction. They concluded that short-term speculators contribute to price overreaction mostly in areas with thinner markets and limited price information.

Recent literature on housing prices and stock market returns suggests that that stock prices of local firms can be influenced by local pricing patterns for housing, alluding to the likelihood that localized shocks in housing wealth influence investor decisions (Anderson and Beracha, 2010). Furthermore, Louis and Sun (2013) by studying the connection between local housing 
price growth and long-term abnormal growth of local firms established a negative relationship between past increases in housing prices and abnormal stock returns.

In the relatively limited literature investigating the effect of motivation on housing prices Springer (1996) and Glower et al. (1998) by considering the influence of seller motivation on marketing time and prices found that seller motivation affects the actual selling price, thus indicating a willingness to sacrifice a higher selling price for faster sales. Finally, Glaeser et al. (2017) in a study on the Chinese housing market argued that two motivations prevail when it comes to housing purchase; it is an investment vehicle for wealth preservation as well as a marriage necessity brought about by culture.

Taking stock of the outlined literature review, this paper focuses on the determination of housing price rationality by accounting for buyers' motivation. In this respect, it constitutes one of the very few studies to consider the perspectives of three different types of housing buyers, namely, owner-occupants, investor-landlords and investor-speculators.

\section{Empirical Investigation}

\section{A. Data and Variables}

For the empirical investigation, annual time series data are collated over the period 1970 to 2016 for 34 countries. (See Table 1 in the appendix for the list of countries used). We consider the clustering of IMF (2016) in which the sample countries are clustered into gloom, bust and boom and boom countries. The gloom cluster consists of 10 economies in which house prices fell substantially during the Global Financial Crisis and have remained on a downward path. The bust and boom cluster consists of 12 economies in which housing markets have rebounded since 2013 after falling sharply during 2007-12. The boom cluster comprises 10 economies in which the drop in house prices in 2007-12 was quite modest and 
was followed by a quick rebound. Last, two economies are unclassified. As can be seen in table 1 in the appendix, the study used clusters of roughly equal size.

The study classified homebuyers into three types: (i) household buyers, (ii) landlords, and (iii) speculators. It postulates that each type of buyer has different motivations for purchasing a house, Equally, rising housing prices cause different reactions of each type of buyer as it affects them disproportionally.

Following Cesa-Bianchi et al. (2015) and by Kishor and Marfatia (2017) we use annual changes in the residential property price index to measure the impact on housing prices. In determining the impact of each buyer type on housing prices, proxies are assigned to represent the buyer type according to their motivation for purchasing. Cultural differences are acknowledged to exist and affect the overall buyer motivation. These will be represented by the cross-section fixed effects specification.

Household buyers have been and continue to be the dominant consumers of housing services. Based on the available data from the Housing Finance Information Network (HOFINET), the average owner occupancy ratio for the countries included in this study is somewhat higher than $71 \%$, with the lowest recorded at $44.1 \%$ in Switzerland and the highest at $91 \%$ in Lithuania.

To represent homebuyer's motivation or interest in purchasing a house, the study uses the price-to-income ratio, measuring affordability thereby ability to consume housing. The priceto-income ratio is among the most widely monitored indicators of housing market conditions (André et al. 2014).

The main data providers were OECD and DataStream. Table 2 in the appendix outlines the variables used and the respective sources while table 3 provides the descriptive statistics. In general, the theory asserts that house prices, rents, and incomes should move in tandem over the long run. If house prices and rents get way out of line, buyers would switch between 
buying and renting, eventually bringing the two in alignment. Similarly, in the long run, the housing prices cannot stray too far from households' ability to afford them. Utilizing the price-to-income index as the proxy variable representing Household willingness to buy we would expect that whenever this ratio increases, the less affordable is housing for perspective Household buyers. Hence, the testable hypothesis suggests that increases in the price-toincome index decreases housing returns.

An alternative and, more realistic proxy might have been to use monthly loan amortization against rent, as well as the down payment to income ratio. This proxy may provide a more accurate measurement of affordability, considering the availability of the substitute good. Due to data availability, we had to drop this variable from our estimation.

Landlords are the second largest buyers of houses, purchasing houses to seek rent from consumers of housing services. Using HOFINET data, the average percentage of housing owned by landlords and rented by consumers is a little over $23 \%$ of total housing stock, with the lowest Lithuania (1.3\%) and the highest Switzerland (51.2\%).

As a proxy for landlord motivation, the study uses the price-to-rent index, which represents the payback period or inversely the yield on the investment. Like the price-to-income ratio, it is also widely monitored and has substantial historical data available. The study uses the percentage change of the price-to-rent index which measures the change in the payback period, while also affecting consumer decision to purchase or rent, motivating landlords' decision to buy. Thus, the testable hypothesis suggests that an increase in the price-to-rent index will likely lead to decreasing housing returns.

Speculators may account for the smallest group of homeowners, but in recent years they may have caused some overreaction in the housing market. Most speculators are short-term investors, like the 'flippers' described by Leung and Tse (2007), whose interests are only to buy low and sell high, without any intention to occupy. Fu and Qian (2014) discovered that 
flippers tend to contribute to price overreaction in areas where markets are thin, and price information is more limited.

Evidence of speculator activity may be detected by the number of vacant housing units as suggested by Leung and Tse (2007). According to HOFINET, (2017) the average vacancy rate for the countries included in this study is about $8.8 \%$, with the highest in Japan $(13.7 \%)$ and the United States (13.6\%) and the lowest in Latvia (0.7\%).

In simulating speculator motivation for home purchase, the study looks towards another market where they may otherwise invest, i.e. the equities market. The equities market provides the same avenue for short-term speculation, with more data pointing to look for potential trends and easier exits. For housing markets to attract speculators, the return should be higher than the equity markets. Hence, the study utilizes the premium or excess of the return in the housing market against that of the capital markets as the proxy. The study hypothesizes that a premium in housing returns over capital markets in the previous period will result in positive housing returns.

A number of control variables have also been introduced to simulate the natural growth of housing prices, following the normal business cycle. Specifically, the paper looks at a country's business conditions for a given year by considering its real GDP growth, inflation level, unemployment rate and interest rates. These variables have been widely used in previous research and found to affect housing prices (see for instance, Baffoe-Bonnie, 1998; Beltratti and Morana, 2010; Cesa-Bianchi et al. 2015; Liu et al. 2016).

In particular, GDP growth serves as a proxy for a country's level of economic activity for any given year. It is also representative of the expansion of household income and thereby capacity to spend. The growth in GDP is expected to have a positive association with housing returns. Consumer price index is used to capture inflation that conditions household spending and saving patterns. It also affects the cost of construction, which then drives up housing 
prices and thereby the respective returns. In turn, a rise in unemployment is expected to have a negative impact on housing returns, as fewer households will be able to secure housing. Finally, long-term government treasuries are used to proxy the mortgage rate, which affects the affordability of credit. Increases in interest rates affect the affordability of credit and thereby housing financed by credit. Thus, higher long-term Treasury yields are expected to result in reduced housing returns.

\section{B. Methodology}

This study uses panel data composing of $N$ cross-sectional units, denoted id $=1, \ldots, N$ and observed across $T$ time periods, denoted $\mathrm{t}=1, \ldots, T$. It covers a cross-section of thirty-four countries $(N=34)$ over a period of 47 years $(T=47)$. Table 2 in the appendix provides the list of variables used along with their sources. Among the various pros for using panel data, Hsiao (2007) indicates that panel data analysis generates more precise extrapolations of model parameters, with more degrees of freedom and less multicollinearity thereby improving the efficiencies of estimates; and that panel data can potentially model complex human behaviour more effectively by considering cross-sections like countries as heterogeneous; (iv) Theoretically able to isolate effects of specific activities, changes and introduction of policies. Broadly, there are three main approaches in panel data analysis (for an extensive technical analysis of the underlying models see Greene, 2017, Alexiou, 2001, and Hsiao 2007).

The empirical specification of the model is a variant of the specifications used in previous literature, particularly the papers by Glindro et al. (2011) and Vogiazas and Alexiou (2017). The model's dynamic nature necessitates the use of dynamic panel data models. These models were initially developed by Holtz-Eakin et al. (1988) and later popularized by Arellano and Bond (1991), commonly referred to as "difference GMM" (Roodman, 2009). 
An augmented version of the model was developed by Arellano and Bover (1995), which was then further developed by Blundell and Bond (1998). This augmented variant is popularly known as system GMM (Roodman, 2009). The GMM framework is effective in dealing with estimation issues: (i) presence of autocorrelation; (ii) issues of heteroskedasticity; (iii) the presence of possible endogeneity of independent variables; (iv) dual causality between variables; (v) omitted variable bias; and (vi) fixed effects that may be correlated with the explanatory variables. Aside from the results of the two-step system GMM, we also provide the estimates of pooled ordinary least squares (OLS) and panel fixed effects (within) specifications.

$$
\begin{aligned}
& H R_{i t}=\beta_{0}+\beta_{1} H R_{i t-1}+\beta_{2} H P E_{i t}+\beta_{3} P T R_{i t}+\beta_{4} P T I_{i t}+\beta_{5} C P I_{i t}+\beta_{6} L T B_{i t}+\beta_{8} G D P_{i t} \\
& \qquad+\beta_{9} U N P_{i t}+\mu_{i t} \\
& \mu_{i t}=\gamma_{i}+\varepsilon_{i t}
\end{aligned}
$$

where $H R$ is the residential price index; $H P E$ is $H R$ minus equity return lagged by one period, serving as the proxy for speculator's interest; PTR is the price to rent ratio index, serving as the proxy for landlord motivation; $P T I$ is the price to rent income index, representing the proxy for household buyers; $C P I$ is the consumer price index; LTB is the Long Term Government Security Yields, which is used as the proxy for long-term mortgage rates; GDP is GDP growth and is used as a proxy for general business environment or the business cycle; UNP denotes unemployment rate. This is a one-way error component regression model, where the $\Upsilon_{i} \mathrm{~S}$ are the non-random parameters to be estimated.

While normal distribution is assumed, the study likewise performs an additional robustness test by running winsorized estimation using the same specification, achieving similar results. In passing it should be stressed that 31 out of 34 countries in our dataset based on the 
definition of the United Nations Statistical Division, are developed. In view of the latter, we also generated separate results using only the developed economies. Relatively similar results are obtained, although HPE somehow becomes insignificant in the results among developed countries the implications of which are discussed in the following section.

\section{Discussion}

Prior to the estimation, the panel unit root tests conducted suggest that all variables are stationary. In addition, a VIF test indicates the absence of multicollinearity. More specifically, all variables have a VIF less than 5. For economy of space, we do not report the unit root nor the VIF tests.

Despite the relatively high coefficient of determination of the pooled, fixed effects and random effects estimations the respective diagnostic tests performed suggest potential heteroscedasticity and autocorrelation issues whilst endogeneity might be also an issue given the dynamic specification of our model. In view of the above, we utilise the system GMM specification, which generates more reliable and robust estimates than other estimators, including the standard first-differences GMM estimator (Soto, 2009). The system GMM estimated coefficients appear robust following the reported results of both the AR(2), Sargan and Hansen Test, which indicate the absence of autocorrelation and validity of the instruments used.

The estimation results, as well as the results of the diagnostic tests, are reported in Table 1. The results of the robustness tests are reported in table 4 (developed countries) and table 5 (winsorized estimates) in the appendix. 
Table 1. Estimation results

\begin{tabular}{|c|c|c|c|c|}
\hline Variable & OLS & Fixed Effects & Random Effects & System GMM \\
\hline$H R_{t-1}$ & & & & $0.183(3.69)^{* * *}$ \\
\hline$H P E_{t-1}$ & $-0.002(-0.75)$ & $-0.002(-0.7)$ & $-0.002(-0.75)$ & $0.008(2.06)^{* *}$ \\
\hline$P T I$ & $0.696(27.26)^{* * *}$ & $0.688(26.57)^{* * *}$ & $0.696(27.26)^{* * *}$ & $0.637(6.04)^{* * *}$ \\
\hline$P T R$ & $0.245(10.72)^{* * *}$ & $0.225(10.06)^{* * *}$ & $0.245(10.72)^{* * *}$ & $0.236(2.14)^{* *}$ \\
\hline$G D P$ & $0.425(15.87)^{* * *}$ & $0.394(14.32)^{* * *}$ & $0.425(15.87)^{* * *}$ & $0.339(5.46)^{* * *}$ \\
\hline$L T B$ & $-0.049(-1.46)$ & $0.017(0.46)$ & $-0.049(-1.46)$ & $0.03(0.63)$ \\
\hline$U N P$ & $-0.044(-3.29)^{* * *}$ & $-0.302(-8.35)^{* * *}$ & $-0.044(-3.29)^{* * *}$ & $-0.023(-1.3)$ \\
\hline$C P I$ & $0.541(10.44)^{* * *}$ & $0.404(7.34)^{* * *}$ & $0.541(10.44)^{* * *}$ & $0.278(2.58)^{* *}$ \\
\hline $\mathrm{R}^{2}$ & 0.91 & 0.92 & 0.91 & \\
\hline Hausman $^{1}$ & $62.23(0.000)$ & & & \\
\hline Wald $^{2}$ & $193(0.000)$ & & & \\
\hline Wooldridge $^{3}$ & $9.89(0.003)$ & & & \\
\hline Number of In & struments & & & 11 \\
\hline $\operatorname{AR}(1)^{4}$ & & & & 0.009 \\
\hline $\operatorname{AR}(2)^{5}$ & & & & 0.179 \\
\hline Sargan $^{6}$ & & & & 0.529 \\
\hline Hansen $^{7}$ & & & & 0.636 \\
\hline \multicolumn{5}{|c|}{$\begin{array}{l}{ }^{1} \text { Fixed effect model is preferred to Random effects; }{ }^{2} \text { The test suggests the presence of heteroscedasticity in the } \\
\text { model; }{ }^{3} \text { The test indicates the presence of first-order serial correlation; }{ }^{4} \text { Test for first-order serial correlation (p- } \\
\text { values); }{ }^{5} \text { Test for second-order serial correlation (p-values); }{ }^{6} \text { Tests the validity of instruments used. Specifically, the } \\
\text { null hypothesis states that there are no over-identified restrictions and thereby the exogenous instruments; } \\
{ }^{7} \text { Alternative test for instrument validity, where the null hypothesis confirms appropriateness of instruments; It is } \\
\text { theoretically superior in cases where there are suspicions of non-sphericity in the error term (due to the Sargan } \\
\text { statistic being inconsistent), as is in the case when robust standard errors are introduced (Roodman, 2009); In the } \\
\text { estimation of system GMM, robust standard errors were used, following Windmeijer's finite-sample correction for } \\
\text { the two-step covariance matrix; } \\
(* * *),(* *) \text { and }(*) \text { denote the significance at the } 1 \%, 5 \% \text { and } 10 \% \text { level respectively with the corresponding t- } \\
\text { statistics of each variable shown in parentheses. }\end{array}$} \\
\hline
\end{tabular}

On the basis of the estimates reported in Table 1 all three types of homebuyers have a statistically significant impact on housing prices, particularly, when considering the System GMM estimates.

Household buyers (PTI) and landlords (PTR) have been consistently significant across all estimated models. Both PTI and PTR, however, bear the wrong sign, indicating, potentially, 
that despite decreasing affordability and long payback period, both households and landlords continue to purchase houses, driving prices further up. This may be due to several factors, one of which could be the presence of broad-based speculative behaviour across all types of homebuyers. The issue of affordability and rental yield may be subrogated by the possibility of capital appreciation, which is in some way assisted by the availability of finance caused by expansion of mortgage credit. Previous literature on the impact of credit supply expansions on housing price has established a positive relationship (see for instance, Bunda and $\mathrm{Ca}^{\prime}$ Zorsi 2010; Kuang 2014 and Favara and Imbs 2015). Availability of credit allows households and landlords to take on speculative bets, but with a longer horizon in mind. Further unlike speculator-flippers who leave properties vacant, households and landlords make use of the property while holding on to it, occupying or leasing the property until it is sold. This implies that even if the property in unaffordable or rental yields considered too low, households and landlords would still procure housing, especially with credit as the mortgage cost is partially subsidized by the benefit received, with an end goal of seeking capital gains through price appreciation.

Speculators (HPE) is found to be significant and of the expected sign in the System GMM model. The results confirm the impact of short-term flippers in the housing market, though appearing to be weak. This could be due to a conglomeration of different countries in the panel data, mixing markets as described by Fu and Qian (2014) with markets with little to no arbitrage opportunity.

When considering only developed countries, however, the impact of speculators becomes statistically insignificant (see table 4 in the appendix). This could be due to developed countries having more robust and developed housing markets, wherein price information is widely available and more transactions take place. These conditions prevent short-term speculators to thrive and contribute to price overreaction (Fu and Qian, 2014). 
As far as the control variables are concerned, GDP growth and inflation, both key indicators of the business cycle are significant bearing the expected signs whilst the mortgage proxy long-term government bond yields (LTB) and unemployment rates are found to be insignificant. Finally, the lagged depended variable is found to significantly affect current housing prices. This could suggest some rationality in households and landlords' optimistic view of continuing price increases, extrapolating from past returns (Scherbina and Schlusche, 2012).

In view of the emerging evidence, it can be argued that the housing market is still dominated by household demand whilst landlords do still affect the market significantly. Traditional households continue to be the major consumer of houses in almost all countries, despite decreasing affordability.

The expansion of credit availability, particularly mortgage and mortgage-backed securities, has made owning houses possible, despite the increasing price-to-income gap. For as long as household disposable income can cover the amortization, it is possible for household buyers to continue purchasing houses, even as the price-to-income ratio spirals out of control.

The unexpected signs of household buyers and landlords exhibit suggest that both types exhibit irrational behaviour in their decisions to procure residential properties. Indeed, the socalled 'irrational exuberance' has been highlighted as one of the driving force behind the financial crisis of 2007-2008 (Verleger, 2016; Case et al., 2013).

Potentially, perceived capital appreciation might be a well-established reason that motivates homebuyers. Scherbina and Schusche (2012) argued that residential real estate markets are dominated by financially unsophisticated households, whose optimistic view of capital appreciation is guided by the presence of momentum, extrapolated from past returns. In the same spirit Huston and Spencer (2014), provide evidence according to which the momentum, expectations of future increases i.e., prices are low, and 'speculative interest in the markets' 
are all significant factors of housing prices. Even though, it might be, to some extent, difficult to assess the rationality of this view considering only capital appreciation, particularly if one is unable to afford the purchase, when combined with the ease of securing credit, it is possible to see why households and landlords may find it reasonable to invest in housing.

In this context, De Bruin et al. (2003) provides further insight into the potential mindset of households and landlords by invoking behavioural assumptions of bounded rationality, whereby actors make decisions based on imperfect knowledge, limited domain information and cognitive powers of calculation. They provide evidence, where social and contextual factors influence the decisions of investors in the housing market. Residential property investors are thought to have a preference towards tried and tested investment vehicles, mindful of past performance with a willingness to endure temporarily low capital returns. Further, it was also found that investors wanted to be personally involved in where they placed their money and favoured steady, reliable income over yield. In other words, the irrational behaviour exhibited by both households and landlord buyers is fully accounted for.

\section{Policy Implications}

In the sketch of the preceding analysis, it follows that households and landlords are driven by expectations of capital gains through price appreciation. Their basis for this expectation is derived from momentum or past performance. In their craving for capital appreciation, they are willing to forego affordability and yield. This behaviour appears to be driven by the availability of financing, following credit booms.

In the aftermath of the Global Financial Crisis, however, this behaviour and increasing divergence between price, income and yield cannot be sustainable. Eventually, disposable income will no longer be able to cover mortgage payments, which may result in a significant drop in demand and thereby prices. In other words, the bubble may eventually burst with 
landlords pulling out, until yields recover significantly. A joint effort by Central Banks and Governments is therefore warranted to ensure the housing market is not disrupted. To avoid challenging issues in the housing sector, the authorities could adopt macroprudential policies but also ensure the availability of credit and housing supply through fiscal and welfare policies. In so far as government intervention has undesired ramification - piercing the bubble - a discretionary combination of monetary and housing policy will be necessary to create a soft landing hence, deflating the bubble.

Furthermore, governments may opt for adjusting the loan-to-value ratios of mortgages or make the requirements for mortgage approvals more stringent. Cerutti et al. (2017) showed that house price booms are more likely to occur in the presence of higher loan-to-value ratios, securitized and wholesale funding sources. Duffy et. al. (2016) and Cronin and Macquinn (2016) however are more sceptical as potential adverse impacts might arise due to adjustments in the loan-to-value and loan-to-income ratios. While it is highly probable that such policies will lead to lower housing prices, at the same time they may stifle the supply of housing stock in the market which in turn will cause rental rates to increase permanently. In a different study, Brueckner et al. (2012) argue that bubble conditions encourage subprime lending, where lender's default concerns are satiated by a collateral which increases in value. Subprime mortgages then create additional demand which could further inflate housing prices, along with the bubble. Immergluck (2008) finds that subprime lending tends to occur in urban areas where housing prices are on the rise, with foreclosure increasing minimally during the uptick but spiking when prices stagnate. Limiting hence, the provision of mortgage to quality lenders would prevent lower-income households to engage in risky activities. In the context of increases in the expected future price of housing due to bubbles in the housing market, Bayar and Neilson (2011) argue that inflated house prices may actually reduce current housing demand, whilst high loan to value loans reduce the effectiveness of monetary 
policy, but raise the volatility of aggregate demand. In this context, tighter borrowing might adversely affect demand volatility at the expense of shrinking the economy.

While intervention can be done through macroprudential policy, there are some possible negative welfare effects on lower-income households, as mentioned earlier. To mitigate these welfare issues, governments need to facilitate the provision of housing financing for lowerincome households. For more on lessons for macroprudential policies in the context of real estate prices see also Duca et al. (2017).

As a supplier for housing, governments can fill the gaps in the housing market, particularly in terms of affordability and availability. In cases where there are shortages in the lower-cost housing supply, the government can assume the role of providing housing. Further, the government can also provide affordable houses by setting prices to match the debt-servicing capacity of households. In providing a set price, the government creates a benchmark for which markets can follow, contributing to the availability of price information, thereby weakening speculator power (Fu and Qian, 2014).

To finance its role as a housing supplier, governments may tap into provident funds or mandated housing funds. Households shall continue to shell out the difference between the house value and the maximum loan-to-value, with the balance taken as a loan deducted out of the household's provident fund contributions. In this manner, the government will be able to cover the cost of provision, without having to rely on household mortgage amortizations. Finally, to avoid undesired disruption of the housing market, government's support should be targeting households at the lower income brackets who cannot afford the housing costs. In addition, resale requirements should be put in place to prevent government-funded housing transforming into a heavily discounted asset. 


\section{Concluding Remarks}

Despite its importance, the housing sector has not received much attention by economists, at least until the Great Recession (Zhu, 2014). This novel study by adopting a dynamic panel data methodology generated results suggesting that households, landlords, and short-term speculators drive significantly the housing returns in a sample of 34 economies clustered as gloom, boom or bust-and-boom ones. For robustness, additional estimates were also performed for developed countries, wherein the speculator proxy was found to be statistically insignificant, possibly indicating a mature housing sector. Overall, the fact that households continue buying houses even when affordability and rental yields drop could reflect an irrational behaviour which might be explained in the context of bounded rationality. More specifically, their buying decisions are to a great extent influenced by an optimistic view of potential appreciation driven by momentum. We further argue that the capacity to buy of households is supported by the availability of credit, allowing households to buy houses they would otherwise not afford. These findings suggest the need for continuous monitoring of the housing sector dynamics, as housing can be untenable in the long run. A combination of macro-prudential and supply side housing policies is proposed to avoid undesired adverse effects on the welfare, particularly of the lower-income families. 


\section{REFERENCES}

Ahir, H., and P. Loungani. (2016). Global House Prices: Time to Worry Again? Available at: https://blogs.imf.org/2016/12/08/global-house-prices-time-to-worry-again/

Alexiou, C. "Crafting a Post Keynesian macroeconomic framework to explain European unemployment: econometric evidence from the European Union countries." Journal of Post Keynesian Economics, 24(1), 2001, 59-80.

Anderson, C., and E. Beracha. "Frothy Housing Markets and Local Stock-Price Movements." Journal of Real Estate Finance and Economics, 45(2), 2012, 326-346.

André, C., L.A. Gil-Alana, and R. Gupta. "Testing for persistence in housing price-to-income and price-to-rent ratios in 16 OECD countries." Journal of Applied Economics, 46(18), 2014, 2127-2138.

Aoki, K., J. Proudman, and G.W. Vlieghe. "House Prices, Consumption, and Monetary Policy: A Financial Accelerator Approach." Journal of Financial Intermediation, 13(4), 2004, 414-435.

Arcelus, F., and A.H. Meltzer. "The Markets for Housing and Housing Services." Journal of Money, Credit and Banking, 5(1), 1973, 78-99.

Arellano, M., and S. Bond. "Some tests of specification for panel data: Monte Carlo evidence and an application to employment equations." The Review of Economic Studies, 58(2), 1991, 277-297.

Arellano, M., and O. Bover. "Another look at instrumental variable estimation of error component." Journal of Econometrics, 68(1), 1995, 29-51.

Baffoe-Bonnie, J. "The Dynamic Impact of Macroeconomic Aggregates on Housing Prices and Stock of Houses: A National and Regional Analysis." Real Estate Finance and Economics, 17(2), 1998, 179-197.

Bayar, O., and W. Neilson. "The peculiar economics of housing bubbles." Contemporary Economic Policy, 29(3), 2011, 374-381.

Beltratti, A., and C. Morana, C. "International house prices and macroeconomic fluctuations." Journal of Banking and Finance, 34(3), 2010, 533-545.

Brueckner, J. K., P.S. Calem and L.I. Nakamurac. "Subprime mortgages and the housing bubble." Journal of Urban Economics, 71(2), 2012, 230-243.

Bunda, I., and M. Ca'Zorzi. "Signals from housing and lending booms." Emerging Markets Review, 11(1), 2010, 1-20.

Case, K.E., J.M., Quigley, and R.J. Schiller. "Wealth Effects Revisited 1975-2012.” Critical Finance Review, 2, 2013, 101-128. 
Cerutti, E., J. Dagher, and G. Dell'Ariccia. "Housing finance and real-estate booms: A crosscountry perspective." Journal of Housing Economics, 38, 2017, 1-13.

Cesa-Bianchi, A., L.F. Cespides, and A. Rebucci. "Global Liquidity, House Prices, and the Macroeconomy: Evidence from Advanced and Emerging Economies." Journal of Money, Credit and Banking, 47, 2015, 301-335.

Cronin, D., and K. McQuinn. "Credit availability, macroprudential regulations and the house price-to-rent ratio.” Journal of Policy Modelling, 38, 2016, 971-984.

De-Bruin, A., and S. Flint-Hartle. "A bounded rationality framework for property investment behavior." Journal of Property Investment and Finance, 21(3), 2003, 271-284.

Duca, J., L. Popoyan and S. Wachter. "Real estate and the great crisis: lessons for macroprudential policy." Contemporary Economic Policy, 2017, forthcoming, doi:10.1111/coep. 12260 .

Duffy, D., N. McInerney, and K. McQuinn. "Macroprudential policy in a recovering property market: too much too soon?" International Journal of Housing Policy, 16(4), 2016, 491-523.

Favara, G., and J. Imbs. "Credit Supply and the Price of Housing. American Economic Review, 105(3), 2015, 958-992.

Fu, Y., and W. Qian. "Speculators and Price Overreaction in the Housing Market." Real Estate Economics, 42(4), 2014, 977-1007.

Gallin, J. "The Long-Run Relationship Between House Prices and Rents." Real Estate Economics, 36(4), 2008, 635-658.

Glaeser, E., W. Huang, Y. Ma, and A. Shleifer. "A Real Estate Boom with Chinese Characteristics.” Journal of Economic Perspectives, 31(1), 2017, 93-116.

Glindro, E.T., T. Subhanij, J. Szeto, and H. Zhu. "Determinants of House Prices in Nine Asia-Pacific Economies.” International Journal of Central Banking, 7(3), 2011, 163-204.

Glower, M., D.R. Haurin, and P.H. Hendershott. "Selling Time and Selling Price: The Influence of Seller Motivation.” Real Estate Economics, 26(4), 1998, 719-740.

Goswami, G., and S. Tan. "Pricing the US residential asset through the rent flow: A crosssectional study." Journal of Banking and Finance, 36(10), 2012, 2742-2756.

Grimes, A. and S. Hyland. "Housing markets and the global financial crisis: the complex dynamics of a credit shock." Contemporary Economic Policy, 33(2), 2014, 315-333.

Greene, W.H. Econometric Analysis (8 ${ }^{\text {th }}$ ed.). Cambridge: Pearson, 2017. Harris, J. "The Effect of Real Rates of Interest on Housing Prices." Journal of Real Estate Finance and Economics, 2(1), 1989, 47-60.

Hiebert, P., and M. Sydow. "What drives returns to euro area housing? Evidence from a dynamic dividend-discount model." Journal of Urban Economics, 70(2/3), 2011, 88-98. 
Ho, L. and G. Wong. "Privatization of public housing: did it cause the 1998 recession in hong kong?" Contemporary Economic Policy, 24(2), 2006, 262-273.

Holtz-Eakin, D., W. Newey and H. Rosen. "Estimating vector autoregressions with panel data." Econometrica 56(6), 1988, 1371-1395.

Hsiao, C. "Panel data analysis - advantages and challenges.” Test, 16(1), 2007, 1-22.

Immergluck, D. "From the Subprime to the Exotic: Excessive Mortgage Market Risk and Foreclosures." Journal of the American Planning Association, 74(1), 2008, 59-76.

International Monetary Fund. "Global House Prices: Time to Worry Again." Available at: https://blogs.imf.org/2016/12/08/global-house-prices-time-to-worry-again/, 2016.

International Monetary Fund. "Global Housing Watch." Available at: http://www.imf.org/external/research/housing/, 2017.

Kishor, N.K., and H.A. Marfatia. (2017). The Dynamic Relationship Between Housing Prices and the Macroeconomy: Evidence from OECD Countries (2017). Journal of Real Estate Finance and Economics, 54(2), 237-268.

Kuang, P. "A model of housing and credit cycles with imperfect market knowledge." European Economic Review, 70, 2014, 419-437.

Lai, R. N., and R. Order. "U.S. House Prices over the Last 30 Years: Bubbles, Regime Shifts and Market (In)Efficiency." Real Estate Economics, 45(2), 2017, 259-300.

Leung, C.K., and C.-Y. Tse. "Flipping in the housing market." Journal of Economic Dynamics and Control, 76, 2017, 232-263.

Liu, R., E. Hui, J. Lu, and Y. Chen. "What Drives Housing Markets: Fundamentals or Bubbles?" The Journal of Real Estate Finance and Economics, 2016, 1-21.

Liu, Z., Miao, J., and Zha, T. "Land Price and Unemployment." Journal of Monetary Economics, 80, 2016, 86-105.

Louis, H., and Sun, A. X. "Long-Term Growth in Housing Prices and Stock Returns." Real Estate Economics, 41(3), 2013, 663-708.

Piazzesi, M., M. Schneider, and S. Tuzel. "Housing, consumption and asset pricing." Journal of Financial Economics, 83(3), 2007, 531-569.

Ramchander, S., M.W. Simpson, and J.R. Webb. "Macroeconomic News and Mortgage Rates. Journal of Real Estate Finance and Economics.” 27(3), 2003, 355-377.

Reichert, A.K. "The Impact of Interest Rates, Income, and Employment upon Regional Housing Prices." Journal of Real Estate Finance and Economics, 3(4), 1990, 373-391. 
Roodman, D. "How to do xtabond2: An introduction to difference and system GMM in Stata.” The Stata Journal, 9(1), 2009, 86-136.

Scherbina, A., and B. Schlusche. "Asset Bubbles: an Application to Residential Real Estate." European Financial Management, 18(3), 2012, 464-491.

Shiller, R.J. "Market Volatility and Investor Behavior." The American Economic Review, 80(2), 1990, 58-62.

Soto, M. "System GMM estimation with a small sample." Barcelona Graduate School of Economics Working Paper no. 395, 2009.

Springer, T.M. "Single-Family Housing Transactions: Seller Motivations, Price, and Marketing Time." Journal of Real Estate Finance and Economics, 13(3), 1996, 237-254.

Verleger, P.K. "The Return of "Irrational Exuberance"." The International Economy, 30(2), 2016, 52-55.

Vogiazas, S., and C. Alexiou. "Determinants of Housing Prices and Bubble Detection: Evidence from Seven Advanced Economies." Atlantic Economic Journal, 45(1), 2017, 119131.

Xiao, Q., and D. Park. "Seoul housing prices and the role of speculation." Empirical Economics, 38(3), 2010, 619-644.

Zhu, M. "Housing Markets, Financial Stability and the Economy." Opening remarks of the Bundesbank/German Research Foundation/IMF Conference, June 2014. 


\section{APPENDIX}

Table 1. The sample of countries and clustering.

\begin{tabular}{|c|c|c|}
\hline & Country & Type of Economy \\
\hline 1 & Australia & Boom \\
\hline 2 & Austria & Boom \\
\hline 3 & Belgium & Boom \\
\hline 4 & Canada & Boom \\
\hline 5 & Chile & Boom \\
\hline 6 & Denmark & Bust and Boom \\
\hline 7 & Finland & Gloom \\
\hline 8 & France & Gloom \\
\hline 9 & Germany & Bust and Boom \\
\hline 10 & Greece & Gloom \\
\hline 11 & Hungary & Bust and Boom \\
\hline 12 & Iceland & Bust and Boom \\
\hline 13 & Ireland & Bust and Boom \\
\hline 14 & Italy & Gloom \\
\hline 15 & Japan & Bust and Boom \\
\hline 16 & Korea, Republic of & Boom \\
\hline 17 & Latvia & Bust and Boom \\
\hline 18 & Lithuania & Bust and Boom \\
\hline 19 & Luxembourg & Unclassified \\
\hline 20 & Netherlands & Gloom \\
\hline 21 & New Zealand & Bust and Boom \\
\hline 22 & Norway & Boom \\
\hline 23 & Poland & Gloom \\
\hline 24 & Portugal & Gloom \\
\hline 25 & Russia & Gloom \\
\hline 26 & Slovak Republic & Boom \\
\hline 27 & Slovenia & Gloom \\
\hline 28 & South Africa & Bust and Boom \\
\hline 29 & Spain & Gloom \\
\hline 30 & Sweden & Boom \\
\hline 31 & Switzerland & Boom \\
\hline 32 & Turkey & Unclassified \\
\hline 33 & United Kingdom & Bust and Boom \\
\hline 34 & United States & Bust and Boom \\
\hline & Total Boom: & 10 \\
\hline & Total Gloom: & 10 \\
\hline & Total Bust and Boom: & 12 \\
\hline & Total unclassified: & 2 \\
\hline
\end{tabular}


Table 2. Definition of Variables and Sources

\begin{tabular}{lll}
\hline Variables & Definition & Source \\
\hline$H R$ & Housing returns (\% change in the housing price index) & OECD \\
$H P E$ & Premium of Housing Returns over Equity Returns & OECD and DataStream \\
$P T R$ & Price to Rent Ratio & OECD \\
$P T I$ & Price to Income Ratio & OECD \\
$C P I$ & Consumer Price Index & OECD \\
$L T B$ & Long-Term Government Security Yield & DataStream \\
$G D P$ & GDP Growth Rate & OECD \\
$U N P$ & Unemployment Rate & DataStream \\
\hline
\end{tabular}

Table 3. Descriptive Statistics of Variables

\begin{tabular}{lllllc}
\hline Variable & Mean & Std. Deviation & Minimum & Maximum & Observations \\
\hline$H R$ & 0.0642398 & 0.08787151 & -0.3730916 & 0.6996566 & 1070 \\
\hline$H P E$ & -0.0426937 & 0.2697992 & -1.809615 & 0.802742 & 942 \\
\hline$P T I$ & 0.0022678 & 0.0641172 & -0.3026341 & 0.3355701 & 937 \\
\hline$P T R$ & 0.0132314 & 0.0795216 & -0.2705436 & 0.6039419 & 1000 \\
\hline$G D P$ & 0.1208448 & 0.4239284 & -0.2268732 & 12.58992 & 1368 \\
\hline$L T B$ & 0.06607 & 0.0370743 & -0.0014 & 0.3743 & 1034 \\
\hline$U N P$ & 0.0946225 & 0.721119 & 0.0043 & 0.5335 & 797 \\
\hline$C P I$ & 0.1226453 & 0.6232682 & -0.0447804 & 12.8144 & 1407 \\
\hline
\end{tabular}


Table 4. Developed Countries Estimates

\begin{tabular}{lllll}
\hline Variable & OLS & Fixed Effects & Random Effects & System GMM \\
\hline HRt -1 & & & & $0.192(3.67)^{* * *}$ \\
HPEt -1 & $-0.004(-0.9)$ & $-0.004(-0.95)$ & $-0.004(-1.06)$ & $0.006(1.47)$ \\
PTI & $0.699(10.35)^{* * *}$ & $0.69(10.19)^{* * *}$ & $0.698(6.3)^{* * *}$ & $0.626(5.75)^{* * *}$ \\
$P T R$ & $0.242(3.61)^{* * *}$ & $0.224(3.4)^{* * *}$ & $0.24(2.08)^{* *}$ & $0.238(2.06)^{* *}$ \\
GDP & $-0.068(-4.34)^{* * *}$ & $-0.306(-6.9)^{* * *}$ & $-0.08(-3.65)^{* * *}$ & $-0.041(-1.59)$ \\
LTB & $-0.044(-0.93)$ & $0.012(0.22)$ & $-0.042(-0.63)$ & $0.029(0.64)$ \\
UNP & $0.532(5.94)^{* * *}$ & $0.418(5.06)^{* * *}$ & $0.522(6.61)^{* * *}$ & $0.263(2.37)^{* *}$ \\
CPI & $0.417(6.12)^{* * *}$ & $0.392(5.68)^{* * *}$ & $0.415(6.51)^{* * *}$ & $0.328(4.68)^{* * *}$ \\
\hline $\mathrm{R}^{2}$ & 0.90 & 0.91 & & 0.90 \\
\hline Number of instruments & & & 11 \\
\hline AR(1) & & & & 0.009 \\
AR(2) & & & & 0.154 \\
Sargan & & & & 0.376 \\
Hansen & & & & 0.493 \\
\hline
\end{tabular}

Table 5. Winsorized Estimates

\begin{tabular}{lllll}
\hline Variable & OLS & Fixed Effects & Random Effects & System GMM \\
\hline HR $_{\mathrm{t}-1}$ & & & & $0.183(3.69)^{* * *}$ \\
$\mathrm{HPE}_{\mathrm{t}-1}$ & $-0.002(-0.75)$ & $-0.002(-0.7)$ & $-0.002(-0.73)$ & $0.008(2.06)^{* *}$ \\
PTI & $0.696(27.26)^{* * *}$ & $0.688(26.57)^{* * *}$ & $0.574(20.64)^{* * *}$ & $0.637(6.04)^{* * *}$ \\
PTR & $0.245(10.72)^{* * *}$ & $0.225(10.06)^{* * *}$ & $0.389(15.19)^{* * *}$ & $0.236(2.14)^{* *}$ \\
GDP & $0.425(15.87)^{* * *}$ & $0.394(14.32)^{* * *}$ & $0.381\left(13.59^{* * *}\right.$ & $0.339(5.46)^{* * *}$ \\
LTB & $-0.049(-1.46)$ & $0.017(0.46)$ & $-0.022(-0.54)$ & $0.03(0.63)$ \\
UNP & $-0.044(-3.29)^{* * *}$ & $-0.302(-8.35)^{* * *}$ & $-0.093(-4.87)^{* * *}$ & $-0.023(-1.3)$ \\
CPI & $0.541(10.44)^{* * *}$ & $0.404(7.34)^{* * *}$ & $0.515(9.87)^{* * *}$ & $0.278(2.58)^{* *}$ \\
\hline $\mathrm{R}^{2}$ & 0.90 & 0.92 & 0.91 & \\
\hline Number of instruments & & & 0.009 \\
\hline AR(1) & & & & 0.179 \\
AR(2) & & & & 0.529 \\
Sargan & & & & 0.636 \\
Hansen & & & & \\
\hline
\end{tabular}

